\title{
Autologous Natural Killer Cell/Natural Killer T Cell Immunotherapy of Malignant Diseases
}

\author{
Aaron J. Smith, John Oertle, Dino Prato \\ Envita, Scottsdale, AZ, USA \\ Email: Aaron@Envita.com, JohnO@envita.com, DinoPrato@envita.com
}

Received 7 July 2014; revised 6 August 2014; accepted 5 September 2014

Copyright (C) 2014 by authors and Scientific Research Publishing Inc.

This work is licensed under the Creative Commons Attribution International License (CC BY). http://creativecommons.org/licenses/by/4.0/

(c) (7) Open Access

\begin{abstract}
Adoptive immunotherapy, the therapeutic infusion of $e x$ vivo activated cancer-fighting white blood cells that was pioneered by Dr. Steven Rosenberg over 30 years ago, has become more widespread due to outstanding published research documenting the clinical efficacy of this strategy. Based on the well-established in vivo functions of NK and NKT cells, their integral role in the efficacy of certain chemotherapeutic and immunomodulatory agents, and their direct therapeutic action as displayed in clinical trials, the use of autologous natural killer cell infusions is an appropriate and warranted therapeutic option for the treatment of malignant diseases, especially in patients whose disease is refractory to standard treatments such as chemotherapy and radiation.
\end{abstract}

\section{Keywords}

Cancer, Immunotherapy, Autologous, Natural Killer Cells (NK Cells), Natural Killer T Cell (NKT Cells), Lymphocyte Activated Killer Cells (LAK cells)

\section{Introduction}

Cancer has recently surpassed heart disease as the leading cause of death in the United States. The American Cancer Society estimated 1,665,540 new cases of cancer in the U.S. in 2014, with 585,720 cancer-related deaths. While the most common treatments for cancer continue to be surgery, chemotherapy and radiation, recent developments in the field of immunotherapy have dramatically elevated the stature of this treatment option. Over the last 40 years, a state of broad-spectrum immune suppression has been repeatedly described in patients with virtually all pathologies of cancer. Decreased immune function and competency have been implicated as being independent prognostic factors of disease progression and poor survival rate in many types of cancer. The importance of natural killer cells (NK) in immune surveillance and early tumor rejection has been established by numerous published research studies and clinical trials. More recently, the role of natural killer T cells (NKT) in 
the regulation of immune responses has also been elucidated. Decreased number or function of NK and NKT cells tends to predispose patients to more aggressive tumor growth, with NK/NKT cell number and antitumor function continuing to decline as disease progresses [1]. NK cell and/or NKT cell activity and tumor infiltration rates have been established as independent prognostic factors in several malignancies [2]-[10]. Restoration of NK cell number and function by means of chemotherapy, immunomodulatory agents or adoptive immunotherapy typically leads to enhanced cellular immune response to tumor and higher survival rate, as demonstrated in animal studies and human clinical trials [2] [11]-[30]. Despite the seemingly universal in vivo immune suppression observed in malignancies, the ex vivo expansion and activation of antitumor effector cells, including NK and NKT cells, from cancer patients has been demonstrated. The use of NK and NKT cells as an effective component of adoptive immunotherapy protocols has been validated by clinical trials performed at Stanford University Medical Center and the University of Minnesota Cancer Center. However, these studies focused only on patients with Hodgkin's disease, non-Hodgkin's lymphoma or acute myeloid leukemia. The potential implications of immunotherapy involving autologous NK/NKT cells include longer life span of cancer patients in addition to cancer regression.

\section{Natural Killer Cells and Natural Killer T Cells}

In 1976, Herberman and colleagues were among the first to report that the cytotoxic activities of certain lymphoid cells were distinct from T-cell mediated cytotoxicity [31]. These cells were eventually termed "natural killer cells" due to their ability to spontaneously lyse tumor cells in vitro. Natural killer (NK) cells comprise roughly $10 \%$ of circulating peripheral blood lymphocytes in the body [32]-[35]. Despite their relative scarcity, NK cells are among the most important components of the immune system, especially the innate immune response. Classic NK cells are phenotypically $\mathrm{CD}^{-} \mathrm{CD}^{-} 6^{+}$, and are a distinct cellular subset from $\mathrm{T}$ lymphocytes, which are $\mathrm{CD}^{+}$[32] [33] [35]-[38]. The predominant characteristic of NK cells is their ability to kill cellular targets, including tumor cells and virally infected cells, without MHC restriction [32] [33] [35] [39]. In contrast, $\mathrm{T}$ cell-mediated cytotoxicity is restricted by MHC recognition. Because metastasized cancer cells generally lack MHC expression, NK cells are the body's primary defense against metastatic disease [32] [37]. NK cells are also potent producers of interferon-gamma, a key cytokine that drives antitumor cellular immune responses [34]-[36]. Perhaps most importantly, NK cells exert their cytotoxic effects with great specificity and without harming host tissue [34]-[36] [39].

Natural killer T cells (NKTs) have only recently been fully characterized phenotypically, and their importance in immune function and regulation is still being elucidated. While NK cells do not express CD3 or other classical T cell markers such as CD4 or CD8, NKT cells express surface markers common to both the T cell and NK cell [35]. NKTs are powerful regulators of the immune system, primarily through cytokine secretion [40] [41]. $\mathrm{CD}^{+}{ }^{+}$NKTs exhibit potent anti-tumor activity in vitro and in vivo, and help coordinate the innate and adaptive immune responses, in part by their own prolific secretion of interferon-gamma [42]-[44].

\section{Depressed NK/NKT Cell Function in Cancer}

Over the last 30 years, a state of broad-spectrum immune suppression has been repeatedly described in patients with virtually all pathologies of cancer. In particular, the depressed ability of NK cells from cancer patients to lyse NK-sensitive cancer cells in vitro has been reported extensively [1] [11]-[16] [45]-[74]. In 1983, Balch and colleagues published a major study that assessed NK activity in 247 cancer patients and 146 age- and sexmatched controls [1]. In this cohort, patients presenting with either breast, colon, head and neck, or lung cancers had significantly depressed NK activity compared to controls [1]. In 1984, Strayer and colleagues noted a significant depression of NK activity in individuals with high familial incidences of cancer, compared to those with little or no familial incidences of cancer [45]. This trend was independent of sex, age and smoking habits [45]. Strayer's group later noted a specific correlation between low NK activity and familial incidence of breast cancer [46]. Significantly depressed NK activity has been reported in breast [46] [47], colon [48] and head and neck cancers [11]-[14] [49] [50], liver cancer [15] [51]-[53], leukemia [54]-[56], lung cancer [57] [63], melanoma [49] [57] [63], ovarian cancer [16] [65] [67], pancreatic cancer [68] [69], prostate cancer [70]-[73] and renal cell carcinoma [74]. Likewise, significant depression of NKT cell number and/or function has been noted in patients with breast cancer [75] [76], colon cancer [76], head and neck cancer [76], lung cancer [77] [78], melanoma [75] 
[76], multiple myeloma [79], prostate cancer [80] and renal cell carcinoma [76].

\section{Prognostic Significance of NKs and NKTs in Cancer Patients}

Significant correlations between immune suppression and disease stage, disease progression, and survival rate have been described for several cancers [2] [11]-[30]. For example, loss of MHC Class I molecules from tumors, which results in NK cell activation, is prognostic of increased survival in breast cancer [17]. Natural killer cell number and/or function have been identified as independent prognostic factors in many cancers, including breast [18], colon [19]-[21], gastric [23] [24] and head and neck cancers [11] [14] [25] [26], liver cancer [15], leukemia [27], non-Hodgkin's lymphoma [28] and ovarian [16] [29] and prostate [30] cancers. Depressed NK function or number is prognostic of increased risk of recurrence, metastasis, and death, whereas increased NK function is prognostic of decreased incidence of metastasis and increased chance of progression-free survival and overall survival [2] [11]-[30]. Further, the intensity of NK cell infiltration into tumors, evaluated by histochemical analysis, is also of prognostic value in colon cancer [2]-[4], gastric cancer [5] [6], lung cancer [7] [8] and renal cell carcinoma [9]. Additionally, NKT cell infiltration is a prognostic factor in colon cancer [10]. As is the case with NK activity and tumor infiltration, increased NK/NKT infiltration is prognostic for decreased incidence of metastasis, increased chance of progression-free survival and overall survival.

Several studies have demonstrated the ability of chemotherapeutic agents, such as paclitaxel [81]-[83], docetaxel [83] [84], tamoxifen [85] [86], cimetidine [16] and indomethacin [87], to enhance NK activity in cancer patients. Researchers at Harvard University have demonstrated that multiple myeloma patients responding to thalidomide treatment exhibited significant increases in NK cell number and anti-tumor activity than did nonresponding patients [88] [89]. In these studies, thalidomide directly enhanced NK function against multiple myeloma cells [88] [89]. Similarly, patients with gastrointestinal stromal tumors that received and responded to Gleevec, exhibited a significant increase in NK function compared to non-responding patients [90].

\section{Expansion of Anti-Tumor Effector Cells from Cancer Patients}

Despite the seemingly universal in vivo immune suppression seen in malignancy, several published studies have demonstrated the feasibility of expanding potent anti-tumor effector cells from the blood of patients with virtually all types of malignancy [91]-[104] [105]-[122]. The ex vivo expansion of NK, NKT, and lymphocyte-activated killer cells (LAK) cells for non-immunotherapeutic purposes has been described for patients with hepatocellular carcinoma, leukemia, lung cancer, ovarian cancer, and prostate cancer. Peng and colleagues demonstrated that activated NKs can be efficiently expanded from hepatocellular carcinoma (HCC) patients [91]. NKs and/or NKTs have been successfully expanded and activated from the peripheral blood of patients with acute myelogenous leukemia [92] [93], chronic myelogenous leukemia [94] [95], acute lymphocytic leukemia [96] and chronic lymphocytic leukemia [97] and in each instance these expanded cells exhibited in vitro cytotoxicity against either autologous or allogeneic leukemia cells. LeFever et al. noted that LAK cells could be expanded from lung cancer patients despite significant baseline depression of in vitro cytotoxicity against tumor targets [61]. Allavena and Lucci reported similar results in generating functional LAK cells from ovarian cancer patients [65] [98]. Activated NKs and NKTs have been expanded from the blood of prostate cancer patients, with these cells showing potent cytotoxicity against prostate cancer cell lines in vitro [99] [100].

\section{Adoptive Immunotherapy of Cancer}

Dr. Steven Rosenberg of the National Cancer Institute first reported in 1985 that the administration of LAKs could achieve clinical responses in patients with colorectal cancer, lung cancer, melanoma or renal cell carcinoma [101]. Rosenberg's later studies demonstrated the safety, efficacy and minimal toxicity of LAK cell infusions in these patients [102]-[104]. LAK cells are generated in vitro using high-dose cytokines, namely IL-2. The antitumor effect of LAK cells has been shown to be mainly due to the presence of NK cells in the LAK population [32] [37] [38] [123]. Rosenberg's group eventually focused solely on the adoptive immunotherapy of malignant melanoma [105]-[108]. Most recently, this group reported that 18 of 35 metastatic melanoma patients treated with adoptive immunotherapy experienced objective clinical responses, defined as a minimum $50 \%$ reduction in tumor burden [107] [108].

In vitro generation of autologous effector cells for adoptive immunotherapy of cancer has been repeatedly 
shown to be feasible. Adoptive immunotherapy has been demonstrated to be safe, well-tolerated and to have at least modest efficacy in the treatment of human cancers, including breast cancer [109], gliomas [110]-[113], liver [114] and lung [115] cancers, lymphoma [116], leukemia [117], ovarian [118] [119] and pancreatic [120] cancers, and renal cell carcinoma [121] [122]. Specifically, NK or NKT cell-based immunotherapy has been utilized in breast cancer [109], gliomas [111], hepatocellular carcinoma [114], Hodgkin's and non-Hodgkin's lymphoma [116], acute myelogenous leukemia [117], renal cell carcinoma [122], colorectal carcinoma [124], gastric carcinoma [125], nonsmall cell lung cancer [126], with clinical success. Miller et al. reported complete remissions in 5 of 19 poor prognosis AML patients treated with NK cell infusions and high-dose cyclophosphamide and fludarabine [117]. Following immunotherapy consisting of autologous NKT cell infusions, Leemhuis and colleagues reported clinical responses in 4 of 9 Hodgkin's/non-Hodgkin's lymphoma patients who were previously refractory to chemotherapy [116]. Further, the ability of NK cells to infiltrate and eliminate metastatic tumors has been demonstrated in humans and in animal models [4] [7] [121] [127]-[129].

Recently, a method for the clinical-scale expansion and activation of natural killer cells and natural killer $\mathrm{T}$ cells for adoptive immunotherapy purposes has been reported. [130] Recent clinical trials involved NKT celltargeted immunotherapy for patients with non-small cell lung cancer was well tolerated with no severe adverse events associated with the cell therapy [131] [132]. A significant increase in peripheral blood mononuclear cells (PBMC) production of IFN- $\gamma$ was detected in 10 of the 17 patients that received treatment [133]. Alpha-galactosylceramide ( $\alpha$-GalCer)-reactive IFN- $\gamma$ forming cells look as if they included both NKT and NK cells [134] [135]. Even though these patients did not show significant tumor regression, a significantly prolonged median survival time (MST) of 29.3 months for patients with higher IFN- $\gamma$ as compared to a MST of 9.7 month those with lower IFN- $\gamma$ levels [133].

\section{Concluding Remarks}

The adoption of immunotherapy as a means to treat cancer has recently been reinvigorated in scientific discussion. Autologous NK/NKT treatment has potential to increase the life span as well contribute to cancer regression. The decrease in immune response after chemotherapy makes patients vulnerable to infectious causes of cancer in addition to reducing the capacity for the immune system to stave off cancer respectively. Autologous NK/NKT cultured in ex vivo should be well received among patients with attenuated immunity. Although the capacity of immune surveillance of cancer differs among individuals and individual cancers, the opportunity to treat patients with immunotherapy should be considered as an option to be sure that those circumstances are indeed the case. The current state of autologous immunotherapy with cells cultured in ex vivo is currently expensive. Further development, research and advances in the field of immunotherapy may reduce the cost making autologous NK/NKT treatment more available to patients in the near future. With the promising findings, more research should be performed to perfect and direct the autologous NK/NKT treatment for improvement in patient outcomes.

\section{References}

[1] Balch, C.M., Tilden, A.B., Dougherty, P.A. and Cloud, G.A. (1983) Depressed Levels of Granular Lymphocytes with Natural Killer (NK) Cell Function in 247 Cancer Patients. Annals of Surgery, 198, 192-199. http://dx.doi.org/10.1097/00000658-198308000-00014

[2] Coca, S., Perez-Piqueras, J., Martinez, D., Colmenarejo, A., Saez, M.A., Vallejo, C., Martos, J.A. and Moreno, M. (1997) The Prognostic Significance of Intratumoral Natural Killer Cells in Patients with Colorectal Carcinoma. Cancer, 79, 2320-2328. http://dx.doi.org/10.1002/(SICI)1097-0142(19970615)79:12<2320::AID-CNCR5>3.0.CO;2-P

[3] Watson, N.F., Ramage, J.M., Madjd, Z., Spendlove, I., Ellis, I.O., Scholefield, J.H. and Durrant, L.G. (2006) Immunosurveillance Is Active in Colorectal Cancer as Downregulation but Not Complete Loss of MHC Class I Expression Correlates with a Poor Prognosis. International Journal of Cancer, 118, 6-10. http://dx.doi.org/10.1002/ijc.21303

[4] Menon, A.G., Janssen-van Rhijn, C.M., Morreau, H., Putter, H., Tollenaar, R.A., van de Velde, C.J., Fleuren, G.J. and Kuppen, P.J. (2004) Immune System and Prognosis in Colorectal Cancer: A Detailed Immunohistochemical Analysis. Laboratory Investigation, 84, 493-501. http://dx.doi.org/10.1038/labinvest.3700055

[5] Ishigami, S., Natsugoe, S., Tokuda, K., Nakajo, A., Xiangming, C., Iwashige, H., Aridome, K., Hokita, S. and Aikou, T. (2000) Clinical Impact of Intratumoral Natural Killer Cell and Dendritic Cell Infiltration in Gastric Cancer. Cancer Letters, 159, 103-108. http://dx.doi.org/10.1016/S0304-3835(00)00542-5

[6] Ishigami, S., Natsugoe, S., Tokuda, K., Nakajo, A., Che, X., Iwashige, H., Aridome, K., Hokita, S. and Aikou, T. (2000) 
Prognostic Value of Intratumoral Natural Killer Cells in Gastric Carcinoma. Cancer, 88, 577-583. http://dx.doi.org/10.1002/(SICI)1097-0142(20000201)88:3<577::AID-CNCR13>3.0.CO;2-V

[7] Takanami, I., Takeuchi, K. and Giga, M. (2001) The Prognostic Value of Natural Killer Cell Infiltration in Resected Pulmonary Adenocarcinoma. The Journal of Thoracic and Cardiovascular Surgery, 121, 1058-1063. http://dx.doi.org/10.1067/mtc.2001.113026

[8] Villegas, F.R., Coca, S., Villarrubia, V.G., Jimenez, R., Chillon, M.J., Jareno, J., Zuil, M. and Callol, L. (2002) Prognostic Significance of Tumor Infiltrating Natural Killer Cells Subset CD57 in Patients with Squamous Cell Lung Cancer. Lung Cancer, 35, 23-28. http://dx.doi.org/10.1016/S0169-5002(01)00292-6

[9] Donskov, F., Bennedsgaard, K.M., Hokland, M., Marcussen, N., Fisker, R., Madsen, H.H., Fode, K. and von der Maase, H. (2004) Leukocyte Orchestration in Blood and Tumour Tissue Following Interleukin-2 Based Immunotherapy in Metastatic Renal Cell Carcinoma. Cancer Immunology, Immunotherapy, 53, 729-739. http://dx.doi.org/10.1007/s00262-004-0525-9

[10] Tachibana, T., Onodera, H., Tsuruyama, T., Mori, A., Nagayama, S., Hiai, H. and Imamura, M. (2005) Increased Intratumor Valpha24-Positive Natural Killer T Cells: A Prognostic Factor for Primary Colorectal Carcinomas. Clinical Cancer Research, 11, 7322-7327. http://dx.doi.org/10.1158/1078-0432.CCR-05-0877

[11] Gonzalez, F.M., Vargas, J.A., Lopez-Cortijo, C., Castejon, R., Gorriz, C., Ramirez-Camacho, R., Millan, I. and Durantez, A. (1998) Prognostic Significance of Natural Killer Cell Activity in Patients with Laryngeal Carcinoma. Archives of Otolaryngology, Head and Neck Surgery, 124, 852-856. http://dx.doi.org/10.1001/archotol.124.8.852

[12] Schantz, S.P., Shillitoe, E.J., Brown, B. and Campbell, B. (1986) Natural Killer Cell Activity and Head and Neck Cancer: A Clinical Assessment. Journal of the National Cancer Institute, 77, 869-875.

[13] Schantz, S.P., Brown, B.W., Lira, E., Taylor, D.L. and Beddingfield, N. (1987) Evidence for the Role of Natural Immunity in the Control of Metastatic Spread of Head and Neck Cancer. Cancer Immunology, Immunotherapy, 25, 141148. http://dx.doi.org/10.1007/BF00199955

[14] Schantz, S.P., Savage, H.E., Racz, T., Taylor, D.L. and Sacks, P.G. (1989) Natural Killer Cells and Metastases from Pharyngeal Carcinoma. The American Journal of Surgery, 158, 361-366. http://dx.doi.org/10.1016/0002-9610(89)90134-7

[15] Taketomi, A., Shimada, M., Shirabe, K., Kajiyama, K., Gion, T. and Sugimachi, K. (1998) Natural Killer Cell Activity in Patients with Hepatocellular Carcinoma: A New Prognostic Indicator after Hepatectomy. Cancer, 83, 58-63. http://dx.doi.org/10.1002/(SICI)1097-0142(19980701)83:1<58::AID-CNCR8>3.0.CO;2-A

[16] Kikuchi, Y., Oomori, K., Kizawa, I. and Kato, K. (1986) Augmented Natural Killer Activity in Ovarian Cancer Patients Treated with Cimetidine. European Journal of Cancer and Clinical Oncology, 22, 1037-1043. http://dx.doi.org/10.1016/0277-5379(86)90003-9

[17] Madjd, Z., Spendlove, I., Pinder, S.E., Ellis, I.O. and Durrant, L.G. (2005) Total Loss of MHC Class I Is an Independent Indicator of Good Prognosis in Breast Cancer. International Journal of Cancer, 117, 248-255. http://dx.doi.org/10.1002/ijc.21163

[18] Sabbioni, M.E., Siegrist, H.P., Bacchi, M., Bernhard, J., Castiglione, M., Thurlimann, B., Bonnefoi, H., Perey, L., Herrmann, R., Goldhirsch, A. and Hurny, C. (2000) Association between Immunity and Prognostic Factors in Early Stage Breast Cancer Patients before Adjuvant Treatment. Breast Cancer Research and Treatment, 59, 279-287. http://dx.doi.org/10.1001/archsurg.1987.01400230050009

[19] Tartter, P.I., Steinberg, B., Barron, D.M. and Martinelli, G. (1987) The Prognostic Significance of Natural Killer Cytotoxicity in Patients with Colorectal Cancer. Archives of Surgery, 122, 1264-1268. http://dx.doi.org/10.1001/archsurg.1987.01400230050009

[20] Kondo, E., Koda, K., Takiguchi, N., Oda, K., Seike, K., Ishizuka, M. and Miyazaki, M. (2003) Preoperative Natural Killer Cell Activity as a Prognostic Factor for Distant Metastasis Following Surgery for Colon Cancer. Digestive Surgery, 20, 445-451. http://dx.doi.org/10.1159/000072714

[21] Liljefors, M., Nilsson, B., Skog, A.L.H., Ragnhammar, P., Mellstedt, H. and Frodin, J.E. (2003) Natural Killer (NK) Cell Function Is a Strong Prognostic Factor in Colorectal Carcinoma Patients Treated with the Monoclonal Antibody 17-1A. International Journal of Cancer, 105, 717-723. http://dx.doi.org/10.1002/ijc.11139

[22] Watson, N.F., Spendlove, I., Madjd, Z., McGilvray, R., Green, A.R., Ellis, I.O., Scholefield, J.H. and Durrant, L.G. (2005) Expression of the Stress-Related MHC Class I Chain-Related Protein MICA Is an Indicator of Good Prognosis in Colorectal Cancer Patients. International Journal of Cancer, 118, 1445-1452.

[23] Takeuchi, H., Maehara, Y., Tokunaga, E., Koga, T., Kakeji, Y. and Sugimachi, K. (2001) Prognostic Significance of Natural Killer Cell Activity in Patients with Gastric Carcinoma: A Multivariate Analysis. The American Journal of Gastroenterology, 96, 574-578. http://dx.doi.org/10.1111/j.1572-0241.2001.03535.X

[24] Akiyoshi, T., Koba, F., Arinaga, S. and Ueo, H. (1990) Preoperative Cell-Mediated Immune Function and the Progno- 
sis of Patients with Gastric Carcinoma. Journal of Surgical Oncology, 45, 137-142. http://dx.doi.org/10.1002/jso.2930450302

[25] Schantz, S.P. and Peters, L.J. (1987) Patterns of Recurrence from Head and Neck Cancer. An Immunologic Perspective. American Journal of Clinical Oncology, 10, 469-474. http://dx.doi.org/10.1097/00000421-198712000-00002

[26] Schantz, S.P. and Ordonez, N.G. (1991) Quantitation of Natural Killer Cell Function and Risk of Metastatic Poorly Differentiated Head and Neck Cancer. Natural Immunity and Cell Growth Regulation, 10, 278-288.

[27] Lowdell, M.W., Craston, R., Samuel, D., Wood, M.E., O’Neill, E., Saha, V. and Prentice, H.G. (2002) Evidence That Continued Remission in Patients Treated for Acute Leukaemia Is Dependent Upon Autologous Natural Killer Cells. British Journal of Haematology, 117, 821-827. http://dx.doi.org/10.1046/j.1365-2141.2002.03495.x

[28] Ono, K. (1998) Clinical Significance of Natural Killing Activity in Patients with Advanced Lymphoma. Journal of Clinical Immunology, 18, 132-141. http://dx.doi.org/10.1023/A:1023298917191

[29] Garzetti, G.G., Cignitti, M., Ciavattini, A., Fabris, N. and Romanini, C. (1993) Natural Killer Cell Activity and Progression-Free Survival in Ovarian Cancer. Gynecologic and Obstetric Investigation, 35, 118-120. http://dx.doi.org/10.1159/000292678

[30] Kašctelan, M., Kraljic, I. and Tarle, M. (1992) NK Cell Activity in Treated Prostate Cancer Patients as a Probe for Circulating Tumor Cells: Hormone Regulatory Effects in Vivo. The Prostate, 21, 111-120. http://dx.doi.org/10.1002/pros.2990210204

[31] Herberman, R.B., Holden, H.T., Ting, C.C., Lavrin, D.L. and Kirchner, H. (1976) Cell-Mediated Immunity to Leukemia Virus- and Tumor-Associated Antigens in Mice. Cancer Research, 36, 615-621.

[32] Robertson, M.J. and Ritz, J. (1990) Biology and Clinical Relevance of Human Natural Killer Cells. Blood, 76, 24212438.

[33] Whiteside, T.L. and Herberman, R.B. (1994) Role of Human Natural Killer Cells in Health and Disease. Clinical and Diagnostic Laboratory Immunology, 1, 125-133.

[34] Whiteside, T.L., Vujanovic, N.L. and Herberman, R.B. (1998) Natural Killer Cells and Tumor Therapy. Specificity, Function, and Development of NK Cells, 230, 221-244. http://dx.doi.org/10.1007/978-3-642-46859-9_13

[35] Orange, J.S. and Ballas, Z.K. (2006) Natural Killer Cells in Human Health and Disease. Clinical Immunology, 118, 110. http://dx.doi.org/10.1016/j.clim.2005.10.011

[36] Whiteside, T.L. and Herberman, R.B. (1995) The Role of Natural Killer Cells in Immune Surveillance of Cancer. Current Opinion in Immunology, 7, 704-710. http://dx.doi.org/10.1016/0952-7915(95)80080-8

[37] Vujanovic, N.L., Basse, P., Herberman, R.B. and Whiteside, T.L. (1996) Antitumor Functions of Natural Killer Cells and Control of Metastases. Methods, 9, 394-408. http://dx.doi.org/10.1006/meth.1996.0044

[38] Herberman, R.B. (2002) Cancer Immunotherapy with Natural Killer Cells. Seminars in Oncology, 29, 27-30. http://dx.doi.org/10.1053/sonc.2002.33079

[39] Moretta, L., Bottino, C., Pende, D., Vitale, M., Mingari, M.C. and Moretta, A. (2005) Human Natural Killer Cells: Molecular Mechanisms Controlling NK Cell Activation and Tumor Cell Lysis. Immunology Letters, 100, 7-13. http://dx.doi.org/10.1016/j.imlet.2005.07.004

[40] Lee, P.T., Benlagha, K., Teyton, L. and Bendelac, A. (2002) Distinct Functional Lineages of Human Va24 Natural Killer T Cells. Journal of Experimental Medicine, 195, 637-641. http://dx.doi.org/10.1084/jem.20011908

[41] Berzins, S.P., Smyth, M.J. and Godfrey, D.I. (2005) Working with NKT Cells-Pitfalls and Practicalities. Current Opinion in Immunology, 17, 448-454. http://dx.doi.org/10.1016/j.coi.2005.05.012

[42] Wang, F.S., Liu, M.X., Zhang, B., Shi, M., Lei, Z.Y., Sun, W.B., Du, Q.Y. and Chen, J.M. (2002) Antitumor Activities of Human Autologous Cytokine-Induced Killer (CIK) Cells against Hepatocellular Carcinoma Cells in Vitro and in Vivo. World Journal of Gastroenterology, 8, 464-468.

[43] Baker, J., Verneris, M.R., Ito, M., Shizuru, J.A. and Negrin, R.S. (2001) Expansion of Cytolytic CD8 ${ }^{+}$Natural Killer T Cells with Limited Capacity for Graft-versus-Host Disease Induction Due to Interferon Gamma Production. Blood, 97, 2923-2931. http://dx.doi.org/10.1182/blood.V97.10.2923

[44] Scheffold, C., Kornacker, M., Scheffold, Y.C., Contag, C.H. and Negrin, R.S. (2002) Visualization of Effective Tumor Targeting by CD8 ${ }^{+}$Natural Killer T Cells Redirected with Bispecific Antibody F(ab’) ${ }_{2}$ HER2xCD3. Cancer Research, 62, 5785-5791.

[45] Strayer, D.R., Carter, W.A., Mayberry, S.D., Pequignot, E. and Brodsky, I. (1984) Low Natural Cytotoxicity of Peripheral Blood Mononuclear Cells in Individuals with High Familial Incidences of Cancer. Cancer Research, 44, 370374.

[46] Strayer, D.R., Carter, W.A. and Brodsky, I. (1986) Familial Occurrence of Breast Cancer Is Associated with Reduced Natural Killer Cytotoxicity. Breast Cancer Research and Treatment, 7, 187-192. 
http://dx.doi.org/10.1007/BF01806249

[47] Garner, W.L., Minton, J.P., James, A.G. and Hoffmann, C.C. (1983) Human Breast Cancer and Impaired NK Cell Function. Journal of Surgical Oncology, 24, 64-66. http://dx.doi.org/10.1002/jso.2930240115

[48] Paholyuk, T.D., Zacharzeva, L.M., Koshel, K.V., Oliynichenko, G.P. and Berezhnaya, N.M. (2004) Stage of Differentiation, Proliferative Index of Tumor Cells and Cytotoxic Activity of Peripheral Blood Lymphocytes in Colorectal Cancer Patients. Experimental Oncology, 26, 161-163.

[49] Micksche, M., Vinzenz, K., Kokoschka, E.M. and Kokoschka, R. (1985) Natural Killer Cell Activity in Tumor-Draining Lymph Nodes: Investigations in Patients with Malignant Melanoma and Head and Neck Cancer. Natural Immunity and Cell Growth Regulation, 4, 315-327.

[50] Racz, T., Sacks, P.G., Taylor, D.L. and Schantz, S.P. (1989) Natural Killer Cell Lysis of Head and Neck Cancer. Archives of Otolaryngology, Head and Neck Surgery, 115, 1322-1328. http://dx.doi.org/10.1001/archotol.1989.01860350056015

[51] Brookes, R.H., Kew, M.C. and Rabson, A.R. (1987) Depressed Natural Cytotoxicity but Normal Natural Killer Cytotoxic Factor (NKCF) Production by Mononuclear Cells Derived from Patients with Hepatocellular Carcinoma. Cancer Immunology, Immunotherapy, 25, 149-152. http://dx.doi.org/10.1007/BF00199956

[52] Hirofuji, H., Kakumu, S., Fuji, A., Ohtani, Y., Murase, K. and Tahara, H. (1987) Natural Killer and Activated Killer Activities in Chronic Liver Disease and Hepatocellular Carcinoma: Evidence for a Decreased Lymphokine-Induced Activity of Effector Cells. Clinical Experimental Immunology, 68, 348-356.

[53] Chuang, W.L., Liu, H.W. and Chang, W.Y. (1990) Natural Killer Cell Activity in Patients with Hepatocellular Carcinoma Relative to Early Development and Tumor Invasion. Cancer, 65, 926-930. http://dx.doi.org/10.1002/1097-0142(19900215)65:4<926::AID-CNCR2820650418>3.0.CO;2-U

[54] Apostolopoulos, A., Symeonidis, A. and Zoumbos, N. (1990) Prognostic Significance of Immune Function Parameters in Patients with Chronic Lymphocytic Leukaemia. European Journal of Haematology, 44, 39-44. http://dx.doi.org/10.1111/j.1600-0609.1990.tb00345.x

[55] Verfaillie, C., Kay, N., Miller, W. and McGlave, P. (1990) Diminished A-LAK Cytotoxicity and Proliferation Accompany Disease Progression in Chronic Myelogenous Leukemia. Blood, 76, 401-408.

[56] Orleans-Lindsay, J.K., Barber, L.D., Prentice, H.G. and Lowdell, M.W. (2001) Acute Myeloid Leukaemia Cells Secrete a Soluble Factor That Inhibits T and NK Cell Proliferation but Not Cytolytic Function-Implications for the Adoptive Immunotherapy of Leukaemia. Clinical \& Experimental Immunology, 126, 403-411. http://dx.doi.org/10.1046/j.1365-2249.2001.01692.x

[57] Sibbitt Jr., W.L., Bankhurst, A.D., Jumonville, A.J., Saiki, J.H., Saiers, J.H. and Doberneck, R.C. (1984) Defects in Natural Killer Cell Activity and Interferon Response in Human Lung Carcinoma and Malignant Melanoma. Cancer Research, 44, 852-856.

[58] Weissler, J.C., Nicod, L.P. and Toews, G.B. (1987) Pulmonary Natural Killer Cell Activity Is Reduced in Patients with Bronchogenic Carcinoma. American Review of Respiratory Disease, 135, 1353-1357.

[59] Anderson, T.M., Ibayashi, Y., Holmes, E.C. and Golub, S.H. (1987) Modification of Natural Killer Activity of Lymphocytes Infiltrating Human Lung Cancers. Cancer Immunology, Immunotherapy, 25, 65-68. http://dx.doi.org/10.1007/BF00199303

[60] deShazo, R.D., Moulder, P.V., Bozelka, B. and Chapman, Y. (1987) Diminished Natural Killer-Cell Activity of Interstitial Pulmonary Cell Populations from Patients with Carcinoma of the Lung. Chest, 91, 26-28. http://dx.doi.org/10.1378/chest.91.1.26

[61] LeFever, A.V. and Funahashi, A. (1991) Phenotype and Function of Natural Killer Cells in Patients with Bronchogenic Carcinoma. Cancer Research, 51, 5596-5601.

[62] Nakamura, H., Kawasaki, N., Hagiwara, M., Saito, M., Konaka, C. and Kato, H. (2000) Cellular Immunologic Parameters Related to Age, Gender, and Stage in Lung Cancer Patients. Lung Cancer, 28, 139-145. http://dx.doi.org/10.1016/S0169-5002(99)00133-6

[63] Lin, C.C., Kuo, Y.C., Huang, W.C. and Lin, C.Y. (1987) Natural Killer Cell Activity in Lung Cancer Patients. Chest, 92, 1022-1024. http://dx.doi.org/10.1378/chest.92.6.1022

[64] Jovic, V., Konjevic, G., Radulovic, S., Jelic, S. and Spuzic, I. (2001) Impaired Perforin-Dependent NK Cell Cytotoxicity and Proliferative Activity of Peripheral Blood T Cells Is Associated with Metastatic Melanoma. Tumori, 87, 324329.

[65] Allavena, P., Zanaboni, F., Rossini, S., Merendino, A., Bonazzi, C., Vassena, L., Mangioni, C. and Mantovani, A. (1986) Lymphokine-Activated Killer Activity of Tumor-Associated and Peripheral Blood Lymphocytes Isolated from Patients with Ascites Ovarian Tumors. Journal of the National Cancer Institute, 77, 863-868. 
[66] Berek, J.S., Bast Jr., R.C., Lichtenstein, A., Hacker, N.F., Spina, C.A., Lagasse, L.D., Knapp, R.C. and Zighelboim, J. (1984) Lymphocyte Cytotoxicity in the Peritoneal Cavity and Blood of Patients with Ovarian Cancer. Obstetrics \& Gynecology, 64, 708-714.

[67] Lotzova, E., Savary, C.A., Freedman, R.S. and Bowen, J.M. (1984) Natural Killer Cell Cytotoxic Potential of Patients with Ovarian Carcinoma and Its Modulation with Virus-Modified Tumor Cell Extract. Cancer Immunology Immunotherapy, 17, 124-129. http://dx.doi.org/10.1007/BF00200048

[68] Funa, K., Nilsson, B., Jacobsson, G. and Alm, G.V. (1984) Decreased Natural Killer Cell Activity and Interferon Production by Leucocytes in Patients with Adenocarcinoma of the Pancreas. British Journal of Cancer, 50, 231-233. http://dx.doi.org/10.1038/bjc.1984.168

[69] Marincola, F.M., Siao, D.Y., Drucker, B.J. and Holder Jr., W.D. (1988) Lymphokine-Activated Killer Cell Activity in Patients with Cancer of the Pancreas. Curr Surg, 45, 298-301.

[70] Choe, B.K., Frost, P., Morrison, M.K. and Rose, N.R. (1987) Natural Killer Cell Activity of Prostatic Cancer Patients. Cancer Investigation, 5, 285-291.

[71] Lahat, N., Alexander, B., Levin, D.R. and Moskovitz, B. (1989) The Relationship between Clinical Stage, Natural Killer Activity and Related Immunological Parameters in Adenocarcinoma of the Prostate. Cancer Immunology, Immunotherapy, 28, 208-212. http://dx.doi.org/10.1007/BF00204990

[72] Healy, C.G., Simons, J.W., Carducci, M.A., DeWeese, T.L., Bartkowski, M., Tong, K.P. and Bolton, W.E. (1998) Impaired Expression and Function of Signal-Transducing Zeta Chains in Peripheral T Cells and Natural Killer Cells in Patients with Prostate Cancer. Cytometry, 32, 109-119. http://dx.doi.org/10.1002/(SICI)1097-0320(19980601)32:2<109::AID-CYTO6>3.0.CO;2-G

[73] Wu, J.D., Higgins, L.M., Steinle, A., Cosman, D., Haugk, K. and Plymate, S.R. (2004) Prevalent Expression of the Immunostimulatory MHC Class I Chain-Related Molecule Is Counteracted by Shedding in Prostate Cancer. Journal of Clinical Investigation, 114, 560-568. http://dx.doi.org/10.1172/JCI200422206

[74] Gati, A., Da Rocha, S., Guerra, N., Escudier, B., Moretta, A., Chouaib, S., Angevin, E. and Caignard, A. (2004) Analysis of the Natural Killer Mediated Immune Response in Metastatic Renal Cell Carcinoma Patients. International Journal of Cancer, 109, 393-401. http://dx.doi.org/10.1002/ijc.11730

[75] Crough, T., Purdie, D.M., Okai, M., Maksoud, A., Nieda, M. and Nicol, A.J. (2004) Modulation of Human $\mathrm{V} \alpha 24^{+} \mathrm{V} \beta 11^{+}$NKT Cells by Age, Malignancy and Conventional Anticancer Therapies. British Journal of Cancer, 91, 1880-1886. http://dx.doi.org/10.1038/sj.bjc.6602218

[76] Molling, J.W., Kolgen, W., van der Vliet, H.J., Boomsma, M.F., Kruizenga, H., Smorenburg, C.H., Molenkamp, B.G., Langendijk, J.A., Leemans, C.R., von Blomberg, B.M., Scheper, R.J. and van den Eertwegh, A.J. (2005) Peripheral Blood IFN- $\gamma$-Secreting V $\alpha 24^{+} \mathrm{V} \beta 11^{+}$NKT Cell Numbers Are Decreased in Cancer Patients Independent of Tumor Type or Tumor Load. International Journal of Cancer, 116, 87-93. http://dx.doi.org/10.1002/ijc.20998

[77] Motohashi, S., Kobayashi, S., Ito, T., Magara, K.K., Mikuni, O., Kamada, N., Iizasa, T., Nakayama, T., Fujisawa, T. and Taniguchi, M. (2002) Preserved IFN- $\alpha$ Production of Circulating V 224 NKT Cells in Primary Lung Cancer Patients. International Journal of Cancer, 102, 159-165. http://dx.doi.org/10.1002/ijc.10678

[78] Konishi, J., Yamazaki, K., Yokouchi, H., Shinagawa, N., Iwabuchi, K. and Nishimura, M. (2004) The Characteristics of Human NKT Cells in Lung Cancer-CD1d Independent Cytotoxicity against Lung Cancer Cells by NKT Cells and Decreased Human NKT Cell Response in Lung Cancer Patients. Human Immunology, 65, 1377-1388. http://dx.doi.org/10.1016/j.humimm.2004.09.003

[79] Dhodapkar, M.V., Geller, M.D., Chang, D.H., Shimizu, K., Fujii, S., Dhodapkar, K.M. and Krasovsky, J. (2003) A Reversible Defect in Natural Killer T Cell Function Characterizes the Progression of Premalignant to Malignant Multiple Myeloma. Journal of Experimental Medicine, 197, 1667-1676. http://dx.doi.org/10.1084/jem.20021650

[80] Tahir, S.M., Cheng, O., Shaulov, A., Koezuka, Y., Bubley, G.J., Wilson, S.B., Balk, S.P. and Exley, M.A. (2001) Loss of IFN- $\gamma$ Production by Invariant NK T Cells in Advanced Cancer. The Journal of Immunology, 167, 4046-4050. http://dx.doi.org/10.4049/jimmunol.167.7.4046

[81] Kubo, M., Morisaki, T., Matsumoto, K., Tasaki, A., Yamanaka, N., Nakashima, H., Kuroki, H., Nakamura, K., Nakamura, M. and Katano, M. (2005) Paclitaxel Probably Enhances Cytotoxicity of Natural Killer Cells against Breast Carcinoma Cells by Increasing Perforin Production. Cancer Immunology, Immunotherapy, 54, 468-476. http://dx.doi.org/10.1007/s00262-004-0617-6

[82] Carson, W.E., Shapiro, C.L., Crespin, T.R., Thornton, L.M. and Andersen, B.L. (2004) Cellular Immunity in Breast Cancer Patients Completing Taxane Treatment. Clinical Cancer Research, 10, 3401-3409. http://dx.doi.org/10.1158/1078-0432.CCR-1016-03

[83] Tsavaris, N., Kosmas, C., Vadiaka, M., Kanelopoulos, P. and Boulamatsis, D. (2002) Immune Changes in Patients with Advanced Breast Cancer Undergoing Chemotherapy with Taxanes. British Journal of Cancer, 87, 21-27. 
[84] Mason, K., Staab, A., Hunter, N., McBride, W., Petersen, S., Terry, N. and Milas, L. (2001) Enhancement of Tumor Radioresponse by Docetaxel: Involvement of Immune System. International Journal of Oncology, 18, 599-606.

[85] Haeryfar, S.M., Nagy, E., Baral, E., Krepart, G., Lotocki, R. and Berczi, I. (2000) Antiestrogens Affect Both Pathways of Killer Cell-Mediated Oncolysis. Anticancer Research, 20, 1849-1853.

[86] Baral, E., Nagy, E. and Berczi, I. (1995) Modulation of Natural Killer Cell-Mediated Cytotoxicity by Tamoxifen and Estradiol. Cancer, 75, 591-599. http://dx.doi.org/10.1002/1097-0142(19950115)75:2<591::AID-CNCR2820750224>3.0.CO;2-U

[87] Kundu, N., Walser, T.C., Ma, X. and Fulton, A.M. (2005) Cyclooxygenase Inhibitors Modulate NK Activities That Control Metastatic Disease. Cancer Immunology, Immunotherapy, 54, 981-987. http://dx.doi.org/10.1007/s00262-005-0669-2

[88] Davies, F.E., Raje, N., Hideshima, T., Lentzsch, S., Young, G., Tai, Y.T., Lin, B., Podar, K., Gupta, D., Chauhan, D., Treon, S.P., Richardson, P.G., Schlossman, R.L., Morgan, G.J., Muller, G.W., Stirling, D.I. and Anderson, K.C. (2001) Thalidomide and Immunomodulatory Derivatives Augment Natural Killer Cell Cytotoxicity in Multiple Myeloma. Blood, 98, 210-216. http://dx.doi.org/10.1182/blood.V98.1.210

[89] Hayashi, T., Hideshima, T., Akiyama, M., Podar, K., Yasui, H., Raje, N., Kumar, S., Chauhan, D., Treon, S.P., Richardson, P. and Anderson, K.C. (2005) Molecular Mechanisms Whereby Immunomodulatory Drugs Activate Natural Killer Cells: Clinical Application. British Journal of Haematology, 128, 192-203. http://dx.doi.org/10.1111/j.1365-2141.2004.05286.X

[90] Borg, C., Terme, M., Taieb J., Menard, C., Flament, C., Robert, C., Maruyama, K., Wakasugi, H., Angevin, E., Thielemans K, Le Cesne, A., Chung-Scott, V., Lazar, V., Tchou, I., Crepineau, F., Lemoine, F., Bernard, J., Fletcher, J.A., Turhan, A., Blay, J.Y., Spatz, A., Emile, J.F., Heinrich, M.C., Mécheri, S., Tursz, T. and Zitvogel, L. (2004) Novel Mode of Action of c-Kit Tyrosine Kinase Inhibitors Leading to NK Cell-Dependent Antitumor Effects. Journal of Clinical Investigation, 114, 379-388. http://dx.doi.org/10.1172/JCI21102

[91] Peng, B.G., Liang, L.J., He, Q., Huang, J.F. and Lu, M.D. (2004) Expansion and Activation of Natural Killer Cells from PBMC for Immunotherapy of Hepatocellular Carcinoma. World Journal of Gastroenterology, 10, 2119-2123.

[92] Linn, Y.C., Lau, L.C. and Hui, K.M. (2002) Generation of Cytokine-Induced Killer Cells from Leukaemic Samples with in Vitro Cytotoxicity against Autologous and Allogeneic Leukaemic Blasts. British Journal of Haematology, 116, 78-86. http://dx.doi.org/10.1046/j.1365-2141.2002.03247.x

[93] Linn, Y.C. and Hui, K.M. (2003) Cytokine-Induced Killer Cells: NK-Like T Cells with Cytotolytic Specificity against Leukemia. Leukemia \& Lymphomama, 44, 1457-1462.

[94] Cervantes, F., Pierson, B.A., McGlave, P.B., Verfaillie, C.M. and Miller, J.S. (1996) Autologous Activated Natural Killer Cells Suppress Primitive Chronic Myelogenous Leukemia Progenitors in Long-Term Culture. Blood, 87, 24762485.

[95] Hoyle, C., Bangs, C.D., Chang, P., Kamel, O., Mehta, B. and Negrin, R.S. (1998) Expansion of Philadelphia Chromosome-Negative $\mathrm{CD}^{+}{ }^{+} \mathrm{CD} 56^{+}$Cytotoxic Cells from Chronic Myeloid Leukemia Patients: In Vitro and in Vivo Efficacy in Severe Combined Immunodeficiency Disease Mice. Blood, 92, 3318-3327.

[96] Torelli, G.F., Guarini, A., Maggio, R., Alfieri, C., Vitale, A. and Foa, R. (2005) Expansion of Natural Killer Cells with lytic Activity against Autologous Blasts from Adult and Pediatric Acute Lymphoid Leukemia Patients in Complete Hematologic Remission. Haematologica, 90, 785-792.

[97] Guven, H., Gilljam, M., Chambers, B.J., Ljunggren, H.G., Christensson, B., Kimby, E. and Dilber, M.S. (2003) Expansion of Natural Killer (NK) and Natural Killer-Like T (NKT)-Cell Populations Derived from Patients with BChronic Lymphocytic Leukemia (B-CLL): A Potential Source for Cellular Immunotherapy. Leukemia, 17, $1973-1980$. http://dx.doi.org/10.1038/sj.leu.2403083

[98] Lucci J.A., 3rd, Manetta, A., Cappuccini, F., Ininns, E.K., Dett, C.A., DiSaia, P., Yamamoto, R.S., Berman, M.L., Soopikian, J. and Granger, G.A. (1992) Immunotherapy of Ovarian Cancer. II. In Vitro Generation and Characterization of Lymphokine-Activated Killer T Cells from the Peripheral Blood of Recurrent Ovarian Cancer Patients. Gynecologic Oncology, 45, 129-135. http://dx.doi.org/10.1016/0090-8258(92)90274-M

[99] Oikawa, T., Kawai, K., Ishiwata, I, Ohno, T. and Akaza, H. (2003) Induction of Potent Antitumour Natural-Killer Cells from Peripheral Blood of Patients with Advanced Prostate Cancer. BJU International, 92, 1009-1015. http://dx.doi.org/10.1111/j.1464-410X.2003.04509.x

[100] Wajchman, H.J., Pierce, C.W., Varma, V.A., Issa, M.M., Petros, J. and Dombrowski, K.E. (2004) Ex Vivo Expansion of $\mathrm{CD}^{+} \mathrm{CD}^{2} 6^{+}$and $\mathrm{CD} 8{ }^{+} \mathrm{CD} 56^{-}$Natural Killer T Cells Specific for MUC1 Mucin. Cancer Research, 64, 1171-1180. http://dx.doi.org/10.1158/0008-5472.CAN-3254-2

[101] Rosenberg, S.A., Lotze, M.T., Muul, L.M., Leitman, S., Chang, A.E., Ettinghausen, S.E., Matory, Y.L., Skibber, J.M., Shiloni, E., Vetto, J.T., et al. (1985) Observations on the Systemic Administration of Autologous Lymphokine-Acti- 
vated Killer Cells and Recombinant Interleukin-2 to Patients with Metastatic Cancer. The New England Journal of Medicine, 313, 1485-1492. http://dx.doi.org/10.1056/NEJM198512053132327

[102] Rosenberg, S.A., Lotze, M.T., Muul, L.M., Leitman, S., Chang, A.E., Vetto, J.T., Seipp, C.A. and Simpson, C. (1986) A New Approach to the Therapy of Cancer Based on the Systemic Administration of Autologous Lymphokine-Activated Killer Cells and Recombinant Interleukin-2. Surgery, 100, 262-272.

[103] Lotze, M.T. and Rosenberg, S.A. (1986) Results of Clinical Trials with the Administration of Interleukin 2 and Adoptive Immunotherapy with Activated Cells in Patients with Cancer. Immunobiology, 172, 420-437. http://dx.doi.org/10.1016/S0171-2985(86)80122-X

[104] Topalian, S.L. and Rosenberg, S.A. (1987) Therapy of Cancer Using the Adoptive Transfer of Activated Killer Cells and Interleukin-2. Acta Haematologica, 78, 75-76. http://dx.doi.org/10.1159/000205907

[105] Rosenberg, S.A., Packard, B.S., Aebersold, P.M., Solomon, D., Topalian, S.L., Toy, S.T., Simon, P., Lotze, M.T., Yang, J.C., Seipp, C.A., et al. (1988) Use of Tumor-Infiltrating Lymphocytes and Interleukin-2 in the Immunotherapy of Patients with Metastatic Melanoma. A Preliminary Report. The New England Journal of Medicine, 319, 1676-1680. http://dx.doi.org/10.1056/NEJM198812223192527

[106] Aebersold, P., Hyatt, C., Johnson, S., Hines, K., Korcak, L., Sanders, M., Lotze, M., Topalian, S., Yang, J. and Rosenberg, S.A. (1991) Lysis of Autologous Melanoma Cells by Tumor-Infiltrating Lymphocytes: Association with Clinical Response. Journal of the National Cancer Institute, 83, 932-937. http://dx.doi.org/10.1093/jnci/83.13.932

[107] Rosenberg, S.A. and Dudley, M.E. (2004) Cancer Regression in Patients with Metastatic Melanoma after the Transfer of Autologous Antitumor Lymphocytes. Proceedings of the National Academy of Sciences of the United States of America, 101, 14639-14645. http://dx.doi.org/10.1073/pnas.0405730101

[108] Dudley, M.E., Wunderlich, J.R., Yang, J.C., Sherry, R.M., Topalian, S.L., Restifo, N.P., Royal, R.E., Kammula, U., White, D.E., Mavroukakis, S.A., Rogers, L.J., Gracia, G.J., Jones, S.A., Mangiameli, D.P., Pelletier, M.M., Gea-Banacloche, J., Robinson, M.R., Berman, D.M., Filie, A.C., Abati, A. and Rosenberg, S.A. (2005) Adoptive Cell Transfer Therapy Following Non-Myeloablative but Lymphodepleting Chemotherapy for the Treatment of Patients with Refractory Metastatic Melanoma. Journal of Clinical Oncology, 23, 2346-2357. http://dx.doi.org/10.1200/JCO.2005.00.240

[109] deMagalhaes-Silverman, M., Donnenberg, A., Lembersky, B., Elder, E., Lister, J., Rybka, W., Whiteside, T. and Ball, E. (2000) Posttransplant Adoptive Immunotherapy with Activated Natural Killer Cells in Patients with Metastatic Breast Cancer. Journal of Immunotherapy, 23, 154-160. http://dx.doi.org/10.1097/00002371-200001000-00018

[110] Tsuboi, K., Saijo, K., Ishikawa, E., Tsurushima, H., Takano, S., Morishita, Y. and Ohno, T. (2003) Effects of Local Injection of ex Vivo Expanded Autologous Tumor-Specific T Lymphocytes in Cases with Recurrent Malignant Gliomas. Clinical Cancer Research, 9, 3294-3302.

[111] Ishikawa, E., Tsuboi, K., Saijo, K., Harada, H., Takano, S., Nose, T. and Ohno, T. (2004) Autologous Natural Killer Cell Therapy for Human Recurrent Malignant Glioma. Anticancer Research, 24, 1861-1871.

[112] Hayes, R.L., Arbit, E., Odaimi, M., Pannullo, S., Scheff, R., Kravchinskiy, D. and Zaroulis, C. (2001) Adoptive Cellular Immunotherapy for the Treatment of Malignant Gliomas. Critical Reviews in Oncology / Hematology, 39, 31-42. http://dx.doi.org/10.1016/S1040-8428(01)00122-6

[113] Huang, Y., Hayes, R.L., Wertheim, S., Arbit, E. and Scheff, R. (2001) Treatment of Refractory Recurrent Malignant Glioma with Adoptive Cellular Immunotherapy: A Case Report. Critical Reviews in Oncology/Hematology, 39, 17-23. http://dx.doi.org/10.1016/S1040-8428(01)00120-2

[114] Shi, M., Zhang, B., Tang, Z.R., Lei, Z.Y., Wang, H.F., Feng, Y.Y., Fan, Z.P., Xu, D.P. and Wang, F.S. (2004) Autologous Cytokine-Induced Killer Cell Therapy in Clinical Trial Phase I Is Safe in Patients with Primary Hepatocellular Carcinoma. World Journal of Gastroenterology, 10, 1146-1151.

[115] Chan, B., Lee, W., Hu, C.X., Ng, P., Li, K.W., Lo, G., Ho, G., Yeung, D.W. and Woo, D. (2003) Adoptive Cellular Immunotherapy for Non-Small Cell Lung Cancer: A Pilot Study. Cytotherapy, 5, 46-54.

[116] Leemhuis, T., Wells, S., Scheffold, C., Edinger, M. and Negrin, R.S. (2005) A Phase I Trial of Autologous CytokineInduced Killer Cells for the Treatment of Relapsed Hodgkin Disease and Non-Hodgkin Lymphoma. Biology of Blood and Marrow Transplant, 11, 181-187. http://dx.doi.org/10.1016/j.bbmt.2004.11.019

[117] Miller, J.S., Soignier, Y., Panoskaltsis-Mortari, A., McNearney, S.A., Yun, G.H., Fautsch, S.K., McKenna, D., Le, C., Defor, T.E., Burns, L.J., Orchard, P.J., Blazar, B.R., Wagner, J.E., Slungaard, A., Weisdorf, D.J., Okazaki, I.J. and McGlave, P.B. (2005) Successful Adoptive Transfer and in Vivo Expansion of Human Haploidentical NK Cells in Patients with Cancer. Blood, 105, 3051-3057. http://dx.doi.org/10.1182/blood-2004-07-2974

[118] Sparano, J.A., Fisher, R.I., Weiss, G.R., Margolin, K., Aronson, F.R., Hawkins, M.J., Atkins, M.B., Dutcher, J.P., Gaynor, E.R., Boldt, D.H., et al. (1994) Phase II Trials of High-Dose Interleukin-2 and Lymphokine-Activated Killer Cells in Advanced Breast Carcinoma and Carcinoma of the Lung, Ovary, and Pancreas and Other Tumors. Journal of Immunotherapy with Emphasis on Tumor Immunology, 16, 216-223. 
http://dx.doi.org/10.1097/00002371-199410000-00006

[119] Freedman, R.S., Edwards, C.L., Kavanagh, J.J., Kudelka, A.P., Katz, R.L., Carrasco, C.H., Atkinson, E.N., Scott, W., Tomasovic, B., Templin, S., et al. (1994) Intraperitoneal Adoptive Immunotherapy of Ovarian Carcinoma with TumorInfiltrating Lymphocytes and Low-Dose Recombinant Interleukin-2: A Pilot Trial. Journal of Immunotherapy with Emphasis on Tumor Immunology, 16, 198-210. http://dx.doi.org/10.1097/00002371-199410000-00004

[120] Kobari, M., Egawa, S., Shibuya, K., Sunamura, M., Saitoh, K. and Matsuno, S. (2000) Effect of Intraportal Adoptive Immunotherapy on Liver Metastases after Resection of Pancreatic Cancer. British Journal of Surgery, 87, 43-48. http://dx.doi.org/10.1046/j.1365-2168.2000.01336.x

[121] Brand, J.M., Meller, B., Von Hof, K., Luhm, J., Bahre, M., Kirchner, H. and Frohn, C. (2004) Kinetics and Organ Distribution of Allogeneic Natural Killer Lymphocytes Transfused into Patients Suffering from Renal Cell Carcinoma. Stem Cells and Development, 13, 307-314. http://dx.doi.org/10.1089/154732804323099235

[122] Escudier, B., Farace, F., Angevin, E., Charpentier, F., Nitenberg, G., Triebel, F. and Hercend, T. (1994) Immunotherapy with Interleukin-2 (IL2) and Lymphokine-Activated Natural Killer Cells: Improvement of Clinical Responses in Metastatic Renal Cell Carcinoma Patients Previously Treated with IL2. European Journal of Cancer, 30, 1078-1083. http://dx.doi.org/10.1016/0959-8049(94)90460-X

[123] Melder, R.J., Whiteside, T.L., Vujanovic, N.L., Hiserodt, J.C. and Herberman, R.B. (1988) A New Approach to Generating Antitumor Effectors for Adoptive Immunotherapy Using Human Adherent Lymphokine-Activated Killer Cells. Cancer Research, 48, 3461-3469.

[124] Schmidt-Wolf, I.G., Finke, S., Trojaneck, B., Denkena, A., Lefterova, P., Schwella, N., Heuft, H.G., Prange, G., Korte, M., Takeya, M., et al. (1999) Phase I Clinical Study Applying Autologous Immunological Effector Cells Transfected with the Interleukin-2 Gene in Patients with Metastatic Renal Cancer, Colorectal Cancer and Lymphoma. British Journal of Cancer, 81, 1009-1016. http://dx.doi.org/10.1038/sj.bjc.6690800

[125] Jiang, J., Xu, N., Wu, C., Deng, H., Lu, M., Li, M., Xu, B., Wu, J., Wang, R., Xu, J. and Nilsson-Ehle, P. (2006) Treatment of Advanced Gastric Cancer by Chemotherapy Combined with Autologous Cytokine-Induced Killer Cells. Anticancer Research, 26, 2237-2242.

[126] Wu, C., Jiang, J., Shi, L. and Xu, N. (2008) Prospective Study of Chemotherapy in Combination with Cytokine-Induced Killer Cells in Patients Suffering from Advanced Non-Small Cell Lung Cancer. Anticancer Research, 28, 3997 4002.

[127] Cozar, J.M., Canton, J., Tallada, M., Concha, A., Cabrera, T., Garrido, F. and Osuna, F.R.C. (2005) Analysis of NK Cells and Chemokine Receptors in Tumor Infiltrating CD4 T Lymphocytes in Human Renal Carcinomas. Cancer Immunology, Immunotherapy, 54, 858-866. http://dx.doi.org/10.1007/s00262-004-0646-1

[128] Okada, K., Nannmark, U., Vujanovic, N.L., Watkins, S., Basse, P., Herberman, R.B. and Whiteside, T.L. (1996) Elimination of Established Liver Metastases by Human Interleukin 2-Activated Natural Killer Cells after Locoregional or Systemic Adoptive Transfer. Cancer Research, 56, 1599-1608.

[129] Yang, Q., Hokland, M.E., Bryant, J.L., Zhang, Y., Nannmark, U., Watkins, S.C., Goldfarb, R.H., Herberman, R.B. and Basse, P.H. (2003) Tumor-Localization by Adoptively Transferred, Interleukin-2-Activated NK Cells Leads to Destruction of Well-Established Lung Metastases. International Journal of Cancer, 105, 512-519. http://dx.doi.org/10.1002/ijc.11119

[130] Klingemann, H.G. and Martinson, J. (2004) Ex Vivo Expansion of Natural Killer Cells for Clinical Applications. Cytotherapy, 6, 15-22. http://dx.doi.org/10.1080/14653240310004548

[131] Motohashi, S., Nagato, K., Kunii, N., Yamamoto, H., Yamasaki, K., Okita, K., et al. (2009) A Phase I-II Study of $\alpha$ Galactosylceramide-Pulsedil IL-2/GM-CSF-Cultured Peripheral Blood Mononuclear Cells in Patients with Advanced and Recurrent Non-Small Cell Lung Cancer. The Journal of Immunology, 182, 2492-2501. http://dx.doi.org/10.4049/jimmunol.0800126

[132] Ishikawa, A., Motohashi, S., Ishikawa, E., Fuchida, H., Higashino, K., Otsuji, M., et al. (2005) A Phase I Study of $\alpha$ Galactosylceramide (KRN7000)-Pulsed Dendritic Cells in Patients with Advanced and Recurrent Non-Small Cell Lung Cancer. Clinical Cancer Research, 11, 1910-1917. http://dx.doi.org/10.1158/1078-0432.CCR-04-1453

[133] Motohashi, S., Ishikawa, A., Ishikawa, E., Otsuji, M., Iizasa, T., Hanaoka, H., et al. (2006) A Phase I Study of in Vitro Expanded Natural Killer T Cells in Patients with Advanced and Recurrent Non-Small Cell Lung Cancer. Clinical Cancer Research, 12, 6079-6086. http://dx.doi.org/10.1158/1078-0432.CCR-06-0114

[134] Motohashi, S., Okamoto, Y., Yoshino, I. and Nakayama, T. (2011) Anti-Tumor Immune Responses Induced by iNKT Cell-Based Immunotherapy for Lung Cancer and Head and Neck Cancer. Clinical Immunology, 140, 167-176. http://dx.doi.org/10.1016/j.clim.2011.01.009

[135] Motohashi, S. and Nakayama, T. (2008) Clinical Applications of Natural Killer T Cell-Based Immunotherapy for Cancer. Cancer Science, 99, 638-645. http://dx.doi.org/10.1111/j.1349-7006.2008.00730.x 
Scientific Research Publishing (SCIRP) is one of the largest Open Access journal publishers. It is currently publishing more than 200 open access, online, peer-reviewed journals covering a wide range of academic disciplines. SCIRP serves the worldwide academic communities and contributes to the progress and application of science with its publication.

Other selected journals from SCIRP are listed as below. Submit your manuscript to us via either submit@scirp.org or Online Submission Portal.
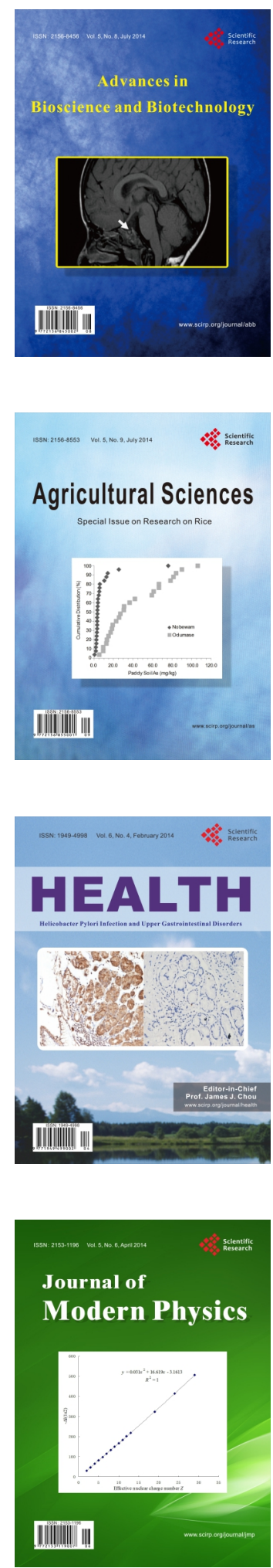
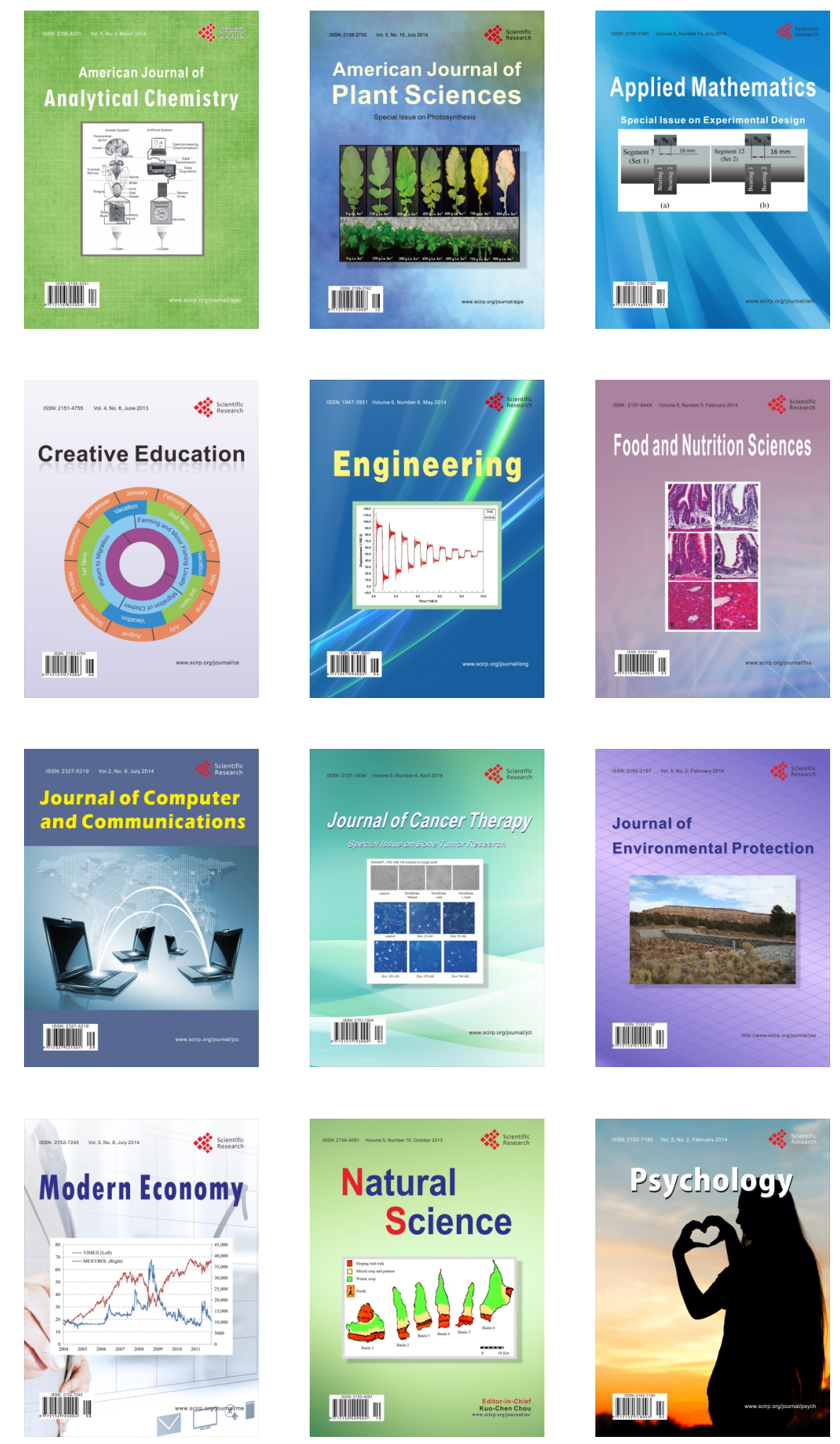